\title{
Natural orifice specimen extraction in colorectal surgery: patient selection and perspectives
}

This article was published in the following Dove Press journal:

Clinical and Experimental Gastroenterology

\section{Kevin M Izquierdo \\ Ece Unal \\ John H Marks}

Division of Colorectal Surgery, Lankenau Medical Center, Wynnewood, PA, USA
Correspondence: John H Marks Division of Colorectal Surgery, Lankenau Medical Center, 100 East Lancaster Avenue, Medical Science Building Suite 375, \#330w, Wynnewood, PA, USA

$\mathrm{Tel}+\mathrm{I} 6106459093$

Email Marks]@MLHS.org

\begin{abstract}
Over the past 30 years, colorectal surgery has evolved to include minimally invasive surgical techniques. Minimally invasive surgery is associated with reduced postoperative pain, reduced wound complications, earlier return of bowel function, and possibly shorter length of hospital stay. These benefits have been attributed to a reduction in operative trauma compared to open surgery. The need to extract the specimen in colorectal operations through a "minilaparotomy" can negate many of the advantages of minimally invasive surgery. Natural orifice specimen extraction (NOSE) is the opening of a hollow viscus that already communicates with the outside world, such as the vagina or distal gastrointestinal tract, in order to remove a specimen. The premise of this technique is to reduce the trauma required to remove the specimen with the expectation that this may improve outcomes. Reduction in postoperative analgesic use, quicker return of bowel function, and shorter length of hospital stay have been observed in colorectal operations with NOSE compared to conventional specimen extraction. While the feasibility of NOSE has been demonstrated in colorectal surgery, failures of this technique have also been described. Selection of patients who can successfully undergo NOSE needs further investigation. This review aims to guide surgeons in appropriately selecting patients for NOSE in colorectal surgery. Patient and specimen characteristics are reviewed in order to define patient populations in which NOSE is likely to be successful. Randomized trials comparing NOSE to conventional specimen extraction in colorectal surgery tend to enroll patients with favorable characteristics (body mass index $<30$, American Society of Anesthesiologists class $\leq 3$, specimen diameter $<6.5 \mathrm{~cm}$ ) and demonstrate improved outcomes. Adopters of NOSE should restrict using this technique to the populations in which feasibility has been defined in the literature. Wider application to other populations, particularly patients with body mass index $>30$ and those with significant comorbidities, requires further study.
\end{abstract}

Keywords: natural orifice specimen extraction, colorectal, minimally invasive surgery, patient selection, rectum, feasibility of NOSE, target organ

\section{History and feasibility}

Colorectal minimally invasive surgery is associated with improved outcomes and fewer complications when compared to open surgery. ${ }^{1-3}$ Despite these advantages, there is significant morbidity that is associated with abdominal wall incisions made for colorectal specimen extraction. In minimally invasive colorectal surgery, the length of the longest incision is dependent upon that which is needed to extract the specimen: the so-called mini-laparotomy. Mini-laparotomies used for specimen extraction are associated with increased wound infection, hernia, and postoperative pain. ${ }^{4-7}$ Natural orifice specimen extraction (NOSE) eliminates extraction site trauma, which is otherwise always needed. NOSE is defined as the removal of a surgical specimen by opening 
a hollow viscus that already communicates with the outside world, such as the gastrointestinal tract or the vagina. Rather than obtaining the specimen through an abdominal incision, a viscerotomy is used for specimen extraction, which allows patients to completely avoid the morbidity associated with larger abdominal incisions. Feasibility of NOSE in colorectal surgery is well documented.

Stewert et $\mathrm{al}^{8}$ and Nezhat ${ }^{9}$ were among the first to report extraction of a colectomy specimen through the vagina in 1991 and 1992. In Nezhat's series, ${ }^{9}$ colectomies with transvaginal specimen extraction were performed for the treatment of endometriosis, though this technique has now been successfully implemented in the treatment of inflammatory bowel disease, diverticulitis, and malignancy. ${ }^{10}$ The first report of partial colectomy with NOSE via the anus was described in 1993 by Franklin et al. ${ }^{11}$ To date, there have been many documented cases in which either the colon, rectum, anus, or vagina has been used to remove both malignant and benign pathology from the cecum to the distal rectum. ${ }^{10}$ Additionally, successful total mesorectal excision has been performed with NOSE, as first described by Person et $\mathrm{al}^{12}$ in 2006.

A barrier to wider adoption of NOSE is technical difficulty. The mini-laparotomy, in some cases, is used to perform a majority of the operation, as in hand-assisted laparoscopy. Adoption of NOSE by surgeons who typically perform colectomies in this fashion would be faced with a steeper learning curve than surgeons who use the mini-laparotomy solely as a specimen extraction site. On that note, intracorporeal anastomosis is a prerequisite skill for those adopting NOSE. Removal of more proximal specimens, as in a right colectomy, requires the presence of a skilled endoscopist who can snare and pull the specimen endoluminally through the length of the distal gastrointestinal tract. Specimen extraction via the vagina requires a posterior colpotomy, an operative maneuver that is not typically performed by general or colorectal surgeons. Furthermore, these technical challenges are amplified by a lack of standardization of the technique.

The demands for these technical skills are more important in removing right-sided colon pathology as compared to left-sided pathology. There are inherent anatomic factors that make NOSE for right-sided colon pathology more difficult. Right colectomy specimens extracted through the lower gastrointestinal tract via distal colotomy must travel the length of the remaining transverse, descending, and sigmoid colon, through the rectum and out of the anus using an endoscope. While this was demonstrated to be feasible in 2010 by Eshuis et al, ${ }^{13}$ it is inherently difficult due to the anatomically narrow and torturous sigmoid colon. In that series, extraction via colotomy failed in 2 of 10 patients due to the bulk of the specimen. This technique is still performed in some centers, though limitations related to the size of the specimen are stricter than for left-sided colon lesions. ${ }^{14}$ This approach has little practicality due to its significant technical challenges, hence its limited use.

The vaginotomy, also called a colpotomy, is a safe technique commonly employed by gynecologists and has been applied in NOSE for both gynecologic and colorectal pathologies. The first recorded vaginal specimen extractions in colorectal surgery were in the 1990s. This technique continues to be implemented, particularly for right-sided colon pathology, given the difficulty of using the distal colon for specimen extraction. A more recent series of right colectomies with NOSE via the vagina was described by Franklin et $\mathrm{al}^{15}$ in 2013. In this series that included 26 transvaginal specimen extractions, feasibility of this method is demonstrated with a complication rate of $7.7 \%$, a rate comparable to conventional specimen removal. Karagul et $\mathrm{al}^{14}$ found that specimens that were too large for transrectal and transanal extraction were successfully removed via the vagina. The obvious restriction of this technique is that it is only an option for female patients.

A greater volume of literature focuses on NOSE for leftsided colon pathology ${ }^{10}$ and is typically performed through a proctotomy. The distal transection point for specimens in the left colon can serve as the viscerotomy in these cases. The distensible rectum lends itself well to passage of specimens for extraction, and anal dilation for retrieval is a relatively simple task. A step-wise description of this technique is described by Wolthuis et al. ${ }^{16}$ Transluminal endoscopic operation (TEO) ports (TEO platform; Storz, Tuttlingen, Germany) have been used in long rectal stumps $(>10 \mathrm{~cm})$ with double-ringed wound protectors (Alexis wound retractor; Applied Medical, Rancho Santa Margarita, CA, USA) used for shorter rectal stumps to facilitate the removal of the specimen. ${ }^{17}$ Other groups have demonstrated removal of specimens without any wound protection. ${ }^{10}$ Theoretically, there exists the possibility of wound implantation with cancer cells in malignant cases. The long-term implications of this, particularly in removing malignant tumors, remain to be seen.

In the treatment of rectal cancer, the transanal total mesorectal excision (taTME) has been well described with promising oncologic results. NOSE, in these cases, is the most practical route of specimen extraction as the rectum or anus serves as the viscerotomy site and needs to be transected 
as a mandatory step in the operation. In December 2008, we performed our first taTME using transanal endoscopic microsurgery equipment (Richard Wolf, Knittlingen, Germany). We now routinely perform NOSE as part of any laparoscopic or robotic transanal-abdominal transanal proctosigmoidectomy and have reported perioperative morbidity and mortality of $13.4 \%$ and $0.3 \%$, respectively, in our series of 373 consecutive patients. ${ }^{18}$

Quality of studies that report on colorectal NOSE outcomes has substantially increased in recent years. Larger series and randomized controlled trials now demonstrate some benefits with NOSE as compared to conventional specimen extraction, particularly in regard to postoperative analgesic use, time to first bowel function, cosmesis, and length of hospital stay. ${ }^{17,19-21}$ With the growing experience in NOSE in colorectal surgery, failures in the technique that ultimately required conventional specimen extraction through an abdominal incision have been reported. More recently, literature about NOSE in colorectal surgery has begun to focus on patient selection and the specific factors that may prevent successful NOSE. Technical feasibility of this technique relies upon careful patient selection, which will be subsequently discussed in greater detail.

\section{Potential benefits}

Several studies suggest some benefit to NOSE over laparoscopy with conventional abdominal wall specimen extraction. Superior outcomes in terms of postoperative pain control, time to first bowel function, hospital length of stay, reduced incisional complications, and improved cosmesis have been demonstrated. ${ }^{17,19-22}$ It should be noted that studies demonstrating these superior outcomes had strict inclusion criteria. Careful examination of patient characteristics in these studies can be used to extrapolate themes that can aid in selecting patients who can most benefit from NOSE in colorectal surgery.

Improved postoperative analgesia in colorectal surgery patients undergoing NOSE is demonstrated by large case series and randomized controlled trials. Several larger case series report lower analgesic use and better pain scores after NOSE. ${ }^{17,19-21,23,24}$ Wolthuis et $\mathrm{al}^{20}$ performed a randomized controlled, single-blinded study to compare postoperative analgesic use between NOSE and conventional specimen extraction groups. The study was powered to show differences in analgesic use after surgery. The NOSE group used significantly less acetaminophen and patient-controlled epidural analgesia. Pain scores remained significantly lower after 1 week.
Quicker return of bowel function, measured by time to first passage of flatus or first bowel movement following surgery, has been described when comparing NOSE to conventional specimen extraction. ${ }^{17,19,21}$ One possible explanation is that postoperative ileus is less common due to decreased manipulation of the bowel and the elimination of bowel exposure to the extracorporeal environment. Earlier bowel function may contribute to shorter length of hospital stay.

Shorter hospital stays have been reported in case-matched studies. ${ }^{17,21}$ Saurabh et $\mathrm{al}^{17}$ showed no increase in readmission rates, in addition to shorter length of hospital stay. Some discrepancy exists, however, as several other studies in the literature show no difference in length of hospital stay compared to conventional specimen extraction. ${ }^{20,23,24}$ A metaanalysis performed by Ma et $\mathrm{al}^{19}$ did show reduced length of hospital stay in patients undergoing NOSE, but heterogeneity in operative technique and recovery pathways suggests that more definitive conclusions about shorter length of hospital stay still require higher-quality clinical trials. A properly powered randomized controlled trial has yet to report on the length of hospital stay in colorectal NOSE.

Incisional-related complications in colorectal surgery have similar rates when comparing open and conventional laparoscopic surgery. Hackert et $\mathrm{al}^{4}$ reported a wound infection rate of $9 \%$ in laparoscopic colorectal surgery in which a mini-laparotomy was used. Kuhry et $\mathrm{al}^{25}$ showed in a meta-analysis that incisional hernia rates in colorectal cancer operations are $10.9 \%$ for open and $7.9 \%$ for laparoscopic surgery with no statistically significant difference between them. These incision-related complications are thought to be linked to the mini-laparotomy. NOSE addresses this by eliminating the need for mini-laparotomy. In a study that compared postoperative complications between NOSE and conventional specimen extraction in sigmoid or rectal cancer, patients having NOSE had significantly lower perioperative complication rates. This was attributed to a significant reduction in incisional wound infection. ${ }^{21}$ While this study was retrospective, with patients assigned to NOSE or conventional specimen extraction based on their own personal choice, the two groups were well matched in their characteristics, particularly in regard to sex, body mass index (BMI), age, American Society of Anesthesiologists (ASA) class, and tumor characteristics. Incisional hernias associated with mini-laparotomies may be avoided by NOSE as well.

Improved cosmesis has been assumed to be superior in patients undergoing NOSE compared to conventional specimen extraction; however, Wolthuis et $\mathrm{al}^{22}$ investigated this more objectively in a case-matched series. They found 
that cosmesis was significantly better in the NOSE group as evaluated by a body image questionnaire and the Patient Scar Assessment Questionnaire. This cosmetic advantage can be factored into selecting patients who could benefit from NOSE in colorectal surgery.

While several benefits of NOSE in colorectal surgery have been demonstrated, the patient populations in which these outcomes have been reported largely include only non-obese patients (BMI $<30 \mathrm{~kg} / \mathrm{m}^{2}$ ) with ASA class of III or less in the setting of elective operations. In this ideal population, superior outcomes are described without significant increases in morbidity. ${ }^{10,17}$ While some studies show benefits of NOSE when directly comparing the method to conventional specimen extraction, much of the data are retrospective from centers that routinely perform NOSE. Wolthuis published a randomized controlled trial that demonstrates significantly reduced pain with NOSE compared to conventional specimen extraction, ${ }^{20}$ but higher-quality studies looking at time to first bowel function, hospital length of stay, and morbidity are lacking. Randomized controlled trials should assess these outcome measures, as initial results in large series of carefully selected populations are encouraging. It is important to note that even in these carefully selected patient cohorts, there are several reports in the literature in which NOSE attempts failed and required extraction of the specimen by conventional means. This highlights the importance of patient selection in utilizing this technique.

\section{Potential pitfalls}

As with any new technique, several concerns are raised with NOSE. Particularly, these issues include infection associated with viscerotomy, breakdown in the closure of the organ used for specimen extraction, pain or functional consequences of disturbing an otherwise healthy organ for specimen extraction, and the potential for seeding unaffected organs in the extraction of malignancy.

Contamination associated with opening a hollow viscus for NOSE, particularly the colon or rectum, has been investigated. It should be noted that bacterial contamination of the operative field is common in laparoscopic surgery, even when specimens are removed by a mini-laparotomy. ${ }^{26}$ Costantino et $\mathrm{al}^{23}$ reported in a case-control study that $100 \%$ of patients who underwent NOSE for sigmoidectomy had peritoneal contamination, compared to $88 \%$ in cases with conventional specimen extraction. However, the study reports no statistical differences in clinical infectious outcomes. The NOSE group of 17 patients reported one patient who developed a 2 $\mathrm{cm}$ pelvic abscess and another who had an anastomotic leak.
Fever of unknown source was reported in two other patients. The matched conventional specimen extraction group of nine patients had no infectious complications. While conclusions about clinically significant infectious risk are difficult to make based on this study, it is worth noting that this study, and several other series, report infectious complication rates that are similar to those reported for laparoscopic colorectal surgery with conventional specimen extraction. In each of these experiences, bowel preparations were performed preoperatively.

In transvaginal NOSE, some have raised concern about the effects of a posterior colpotomy. No complications related to the colpotomy incision have been reported in colorectal surgery. ${ }^{27}$ It is interesting to note that many gynecologists will routinely leave a posterior colpotomy open without any issues in healing. The vagina has many properties that are ideal for specimen extraction, including elasticity, redundant vascular supply lending to excellent healing, clean nature, and relatively easy access. ${ }^{28}$ Concerns about sexual dysfunction after colpotomy have been raised, but there are no reports of this in the literature. Palanivelu et $\mathrm{al}^{29}$ found no dyspareunia in any of the 11 patients in their series after nearly 1 year of follow-up. Kim et $\mathrm{al}^{30}$ demonstrated no rectovaginal fistulas and no dyspareunia at 3-months follow-up in 58 patients who underwent transvaginal specimen extraction. In transanal NOSE, concerns have been raised about incontinence and anal dysfunction; however, both Zhang $^{41}$ and Wolthuis et $\mathrm{al}^{20,31}$ found no anal dysfunction or fecal incontinence associated with this.

Evaluating oncologic outcomes when implementing new surgical techniques is of paramount importance. Shortterm outcomes have been favorable. Margin status has been reported to be similar to conventional specimen extraction. ${ }^{21}$ Nodal harvest has been reported to be well above 12 lymph nodes in several studies. ${ }^{17,21}$ In our series of 373 patients with low rectal cancer who underwent a taTME procedure, many of whom underwent NOSE, we reported $96 \%$ complete/nearcomplete TME specimens, with negative circumferential and distal margins in 94\% and 98.6\%, respectively. Long-term oncologic outcomes in our series are encouraging with $7.4 \%$ overall local recurrence, $19.5 \%$ distant metastasis, and $90 \%$ overall survival at 5 years. ${ }^{18}$

Tumor implantation upon specimen removal via natural orifice is another concern that has been raised. Reports of laparoscopic port site metastasis in the past raise concerns of removing malignant specimens through healthy viscera such as the rectum, anus, or vagina. Variants in wound protection including laparoscopic bags, duel-ring wound protectors, and 
TEO ports have all been used for this purpose. It has been reported that use of these devices can reduce the chance of successful NOSE. Two of 110 such patients of the Wolthuis et al's ${ }^{31}$ experience required removal of wound protectors in order to remove specimens from the anus. Karagul et $\mathrm{al}^{14}$ describe washing the anus and rectum with povidone-iodine before and after specimen removal without using a wound protector. With a mean follow-up of 21.1 months, there has been no reported extraction site metastasis.

Concerns about infection, pain, or functional consequences of the organ used for specimen extraction, and oncologic outcomes in NOSE have been addressed in the literature. While no clear disadvantages have been demonstrated in using organs for specimen extraction, infection rates and oncologic outcomes seem to be similar to conventional specimen extraction.

\section{Patient selection}

The feasibility of NOSE is well documented, but reported failures to complete NOSE suggest that feasibility is highly reliant on patient selection. In the literature, the two prevailing themes that seem to be associated with feasibility of NOSE are patient characteristics, particularly BMI and male sex, and specimen bulk, measured by maximum diameter and size of tumor.

\section{Patient factors}

Patient characteristics including BMI, sex, and comorbidity may influence the feasibility and potential benefit of NOSE in colorectal surgery. Most studies of NOSE exclude patients with BMI >30, ASA class greater than III, and those having emergency surgery. Patient characteristics and overall success rate for completion of NOSE are displayed in Table 1. Failure of NOSE and the reason for failure are reported in many of these studies; yet, patient characteristics in this subset are not commonly provided by authors. Table 2 lists the available patient characteristics in cases of failed NOSE from the literature.

\section{Sex}

Bulky specimens are the most commonly cited reason for NOSE failure in colorectal surgery. The option of NOSE via the vagina appears to be the most significant factor contributing to higher NOSE success in women compared to men. It has been well established that the elastic properties of the vagina allow removal of more bulky specimens when compared to proctotomies. This is best demonstrated by Karagul et al, ${ }^{14}$ in which 12 of 15 women who failed NOSE via the anus were able to have successful NOSE via the vagina. In this series, there was a statistically significant difference in the mean size of extracted specimens via vagina and anus $\left(5.4 \pm 1.4\right.$ and $3.5 \pm 3.1 \mathrm{~cm}$, respectively). ${ }^{14}$ Further demonstrating the elastic properties of the vagina, Yagci et $\mathrm{al}^{32} \mathrm{dem}-$ onstrated transvaginal removal of a 9-cm right-sided colon mass. Independent of specimen size, transvaginal specimen extraction is more technically feasible for removing right colectomy specimens compared to the alternative of moving the right-sided specimen endoscopically through the entire length of the colon.

The question of pelvic shape and anatomy differences between men and women is worth mentioning. Some studies compare transanal NOSE between men and women. While pelvic geometry has not been cited as a reason for NOSE failure, it is unclear how much this may contribute to NOSE failure due to a "bulky specimen". When transanal NOSE for laparoscopic colorectal resections is compared between men and women, the success rates are similar $(40.5 \%$ in men and $50 \%$ in women).${ }^{14}$ It should be pointed out that in these studies comparing men and women, most patients have a BMI $<30$ $\mathrm{kg} / \mathrm{m}^{2}$ and pelvic geometry may become a more significant factor for larger patients, particularly if a higher BMI is correlated to an increase in mesenteric bulk.

\section{Body mass index}

NOSE in colorectal surgery for the obese patient poses unique technical challenges. Increased BMI is associated with increased visceral fat, ${ }^{33}$ which may be associated with specimen bulk. It is well recognized that one of the advantages of minimally invasive surgery is the improved visualization and postoperative outcomes in patients with higher BMI, but as we discussed earlier, the benefit of minimally invasive surgery is diminished by mini-laparotomies made for specimen extraction. While most series exclude patients with BMI $>30$, successful colorectal NOSE has been reported in patients with BMI $>30$. Yagci reported one case in a patient with BMI of $31 \mathrm{~kg} / \mathrm{m}^{2}$, but NOSE required transection of the mesentery - a technique that raises concerns about long-term oncologic outcomes. In Zhang et al's ${ }^{34}$ series of 27 patients, the highest BMI reported with successful NOSE was $28.3 \mathrm{~kg} / \mathrm{m}^{2}$. They report a failure in a patient with BMI $30.2 \mathrm{~kg} / \mathrm{m}^{2}$. Wolthuis et $\mathrm{al}^{31}$ reported successful NOSE in six patients with BMI $>30$, as part of their series of 110 patients. The postoperative outcomes for these patients were not discussed separately. As the literature is highly selective in terms of BMI, this should be considered a significant factor in assessing whether or not NOSE will be technically feasible when planning an 
Table I Patient and specimen characteristics for NOSE in colorectal surgery

\begin{tabular}{|c|c|c|c|c|c|c|}
\hline Study group & $\begin{array}{l}\text { Successful } \\
\text { NOSE/total } \\
\text { attempted }\end{array}$ & $\begin{array}{l}\text { Success } \\
\text { rate (\%) }\end{array}$ & $\operatorname{Sex}(M / F)$ & $\begin{array}{l}\text { Age (years) } \\
\text { Mean (range) }\end{array}$ & BMI mean (range) & Comorbidity \\
\hline $\begin{array}{l}\text { Wolthuis et al, }{ }^{20} \\
2015\end{array}$ & $19 / 20$ & 95 & $5 / 15$ & $\begin{array}{l}54 \text { (median) } \\
(3 \mathrm{I}-72)\end{array}$ & 23.5 (18-29) & $\begin{array}{l}\text { ASA } I=5 \\
\text { ASA } \|=15\end{array}$ \\
\hline Saurabh et al, ${ }^{17} 2017$ & $77 / 82$ & 93.9 & $47 / 35$ & $63.3 \pm 13.9$ & $24.4 \pm 4.2$ & $\begin{array}{l}\text { ASA } I=59 \\
\text { ASA } I / I I I=23\end{array}$ \\
\hline Karagul et al, ${ }^{14} 2017$ & $49 / 67$ & 73.1 & $40 / 27$ & $57.9 \pm 13.4$ & Unk & Unk \\
\hline $\begin{array}{l}\text { Wolthuis et al, }{ }^{37} \\
2015\end{array}$ & $17 / 17$ & 100 & $3 / 15$ & $\begin{array}{l}\text { Camera sleeve: } 63 \\
\text { (median) (range: } 47-69 \text { ) } \\
\text { Specimen bag: } 51 \\
\text { (median) (range: } 40-56 \text { ) }\end{array}$ & $\begin{array}{l}\text { Camera sleeve: } 23 \\
\text { (median) (range } 21-25 \text { ) } \\
\text { Specimen bag: } 22 \\
\text { (median) (range: } 20-24 \text { ) }\end{array}$ & $\begin{array}{l}\text { ASA I=4 } \\
\text { ASA } I=I I \\
\text { ASA III=2 }\end{array}$ \\
\hline Pai et al, ${ }^{38} 2015$ & $19 / 19$ & 100 & $13 / 6$ & $\begin{array}{l}48 \text { (median) (range: } \\
23-78)\end{array}$ & Unk & Unk \\
\hline $\begin{array}{l}\text { Palanivelu et al, }{ }^{29} \\
2008\end{array}$ & $7 / 7$ & 100 & $0 / 7$ & 49.5 (mean) & 25.3 & Unk \\
\hline $\begin{array}{l}\text { Nishimura et al, }{ }^{39} \\
2013\end{array}$ & $5 / 5$ & 100 & $0 / 5$ & $\begin{array}{l}67.4 \text { (mean) (range: } \\
54-84 \text { ) }\end{array}$ & 21.3 (range: 16.2-27.3) & Unk \\
\hline Wang et al, ${ }^{40} 2013$ & $21 / 21$ & 100 & $4 / 17$ & $\begin{array}{l}62 \text { (median) (range: } \\
50-80)\end{array}$ & $\begin{array}{l}23.6 \text { (mean) (range: } \\
18-30)\end{array}$ & Unk \\
\hline Zhang et $\mathrm{al}^{4}{ }^{41} 2014$ & $18 / 18$ & 100 & $10 / 8$ & $\begin{array}{l}56.6 \text { (mean) (range: } \\
48-69)\end{array}$ & $\begin{array}{l}22.6 \text { (mean) (range: } \\
\text { 19.7-26.4) }\end{array}$ & Unk \\
\hline Hisada et $a l,{ }^{24} 2014$ & $20 / 20$ & 100 & $12 / 8$ & $63.7 \pm 9$ & Unk & Unk \\
\hline $\begin{array}{l}\text { Costantino et }\left.a\right|^{23} \\
2012\end{array}$ & $16 / 17$ & 94.1 & $6 / 11$ & $60.1 \pm 9.42$ & $25.47 \pm 3.02$ & $\mid .47 \pm 0.5 \mathrm{I}$ \\
\hline Zhang et al, ${ }^{34} 2014$ & $24 / 27$ & 88.9 & $16 / 11$ & $\begin{array}{l}54.8 \text { (mean) (range: } \\
37-77)\end{array}$ & $\begin{array}{l}\text { 22.II (mean) (range: } \\
\text { I8.4-30.2) }\end{array}$ & Unk \\
\hline Han et al, ${ }^{42} 2013$ & $21 / 21$ & 100 & $12 / 9$ & $45.4 \pm 3.6$ & $23.1 \pm 2.8$ & Unk \\
\hline Meillat et al, ${ }^{43} 2017$ & $7 / 7$ & 100 & $2 / 5$ & Unk & $<25$ & Unk \\
\hline $\begin{array}{l}\text { Wolthuis et al, } \\
2015\end{array}$ & $110 / 110$ & 100 & $13 / 97$ & $\begin{array}{l}38 \text { (median) (range: } \\
32-56)\end{array}$ & $\begin{array}{l}23 \text { (median) (range: } \\
2 \mathrm{I}-25)\end{array}$ & $\begin{array}{l}\text { ASA } I=45 \\
\text { ASA } I=56 \\
\text { ASA III=9 }\end{array}$ \\
\hline $\begin{array}{l}\text { Xingmao et al, }{ }^{21} \\
2014\end{array}$ & $65 / 65$ & 100 & $32 / 33$ & $56.1 \pm 9.3$ & $23.7 \pm 2.9$ & $\begin{array}{l}\text { ASA } I=10 \\
\text { ASA } \|=50 \\
\text { ASA } \| I=5\end{array}$ \\
\hline
\end{tabular}




\begin{tabular}{|c|c|c|c|c|}
\hline $\begin{array}{l}\text { Indication/ } \\
\text { pathology }\end{array}$ & $\begin{array}{l}\text { Viscerotomy } \\
\text { site }\end{array}$ & Location & $\begin{array}{l}\text { Specimen size } \\
(\mathrm{cm})\end{array}$ & Complications \\
\hline $\begin{array}{l}\text { Diverticulitis }=15 \\
C R C=5\end{array}$ & Transanal $=20$ & Left/sigmoid colon & Unk & Anastomotic bleeding $=2(10 \%)$ \\
\hline$C R C=82$ & Transanal $=82$ & $\begin{array}{l}\text { Rectosigmoid }=69 \\
\text { Prox. rectum }=13\end{array}$ & $\begin{array}{l}\text { Largest diameter } \\
2.9 \pm 1.6\end{array}$ & $\begin{array}{l}\text { Anastomotic leak=2 }(2.4 \%) \\
\text { Anastomotic bleeding }=\mathrm{I}(\mathrm{I} .2 \%) \\
\text { Surgical site infection }=0(0 \%) \\
\text { Anal fissure }=2(2.4 \%) \\
\text { Injury to surrounding viscera=I }(\mathrm{I} .2 \%)\end{array}$ \\
\hline $\begin{array}{l}\text { Crohn=2 } \\
\mathrm{FAP}=4 \\
\mathrm{CRC}=6 \mathrm{I}\end{array}$ & $\begin{array}{l}\text { Transanal }=37 \\
\text { Transvaginal }=12\end{array}$ & $\begin{array}{l}\text { Colon: } \\
\text { Right }=17 \\
\text { Transverse }=1 \\
\text { Total }=4 \\
\text { Rectosigmoid }=30\end{array}$ & $4.6 \pm 3.4$ (mean) & $\begin{array}{l}\text { Bladder injury=I }(\mathrm{I} .49 \%) \\
\text { latrogenic sigmoid colon injury=I }(\mathrm{I} .49 \%) \\
\text { Anal trauma }=\mathrm{I}(\mathrm{I} .49 \%)\end{array}$ \\
\hline $\begin{array}{l}\text { Diverticulitis }=7 \\
C R C=5 \\
\text { Endometriosis }=4 \\
\text { Lipoma }=1\end{array}$ & Transanal $=17$ & Left colon $=17$ & $\begin{array}{l}\text { Length: } \\
\text { Camera sleeve: } 23 \\
\text { (median) (range: } \\
\text { 20-26) } \\
\text { Bag: } 21 \text { (median) } \\
\text { (range: } 15-25 \text { ) }\end{array}$ & Unk \\
\hline$C R C=19$ & Transanal $=19$ & Rectum $=19$ & Unk & $\begin{array}{l}\text { Pelvic collection, gap at anastomosis }=I(5.26 \%) \\
\text { Chyle leak }=I(5.26 \%)\end{array}$ \\
\hline $\begin{array}{l}\mathrm{FAP}+\text { rectal } \\
\text { adenocarcinoma }=7\end{array}$ & Transvaginal=7 & Total colon $=7$ & Unk & $\begin{array}{l}\text { lleus=I }(\mid 4.3 \%) \\
\text { Pouchitis=I (I4.3\%) } \\
\text { DVT=I }(14.3 \%)\end{array}$ \\
\hline$C R C=5$ & Transvaginal $=5$ & $\begin{array}{l}\text { Rectosigmoid }=1 \\
\text { Sigmoid }=4\end{array}$ & $\begin{array}{l}\text { I.94 (mean) (range: } \\
0-3.7)\end{array}$ & Chyloperitoneum=I (20\%) \\
\hline$C R C=21$ & $\begin{array}{l}\text { Transanal=16 } \\
\text { Transvaginal=5 }\end{array}$ & Rectum $=2 \mathrm{I}$ & $\begin{array}{l}2.8 \text { (mean) (range: } \\
1.8-6.0)\end{array}$ & lleus $=I$ \\
\hline $\begin{array}{l}\text { Large rectal } \\
\text { adenoma }=18\end{array}$ & Transanal $=\mid 8$ & $\begin{array}{l}\text { Midrectum }=12 \\
\text { Low rectum }=6\end{array}$ & $\begin{array}{l}4.2 \text { (mean) (range: } \\
3.5-6.5)\end{array}$ & None \\
\hline$C R C=20$ & Transanal $=20$ & $\begin{array}{l}\text { Upper rectum/ } \\
\text { sigmoid }=20\end{array}$ & $2.7 \pm 0.9$ & $\begin{array}{l}\text { Anal pain }=\mid(5 \%) \\
\text { Anastomotic ulcer=I }(5 \%) \\
\text { Ischemic colitis=I }(5 \%) \\
\text { Leakage }=I(5 \%)\end{array}$ \\
\hline Diverticulitis $=17$ & Transanal=17 & Sigmoid=17 & Unk & Overall=5 \\
\hline$C R C=27$ & Transanal $=27$ & $\begin{array}{l}\text { Sigmoid }=13 \\
\text { Rectum }=14\end{array}$ & Unk & $\begin{array}{l}\text { Intraperitoneal hemorrhage=I }(3.7 \%) \\
\text { Wound infection }=I(3.7 \%)\end{array}$ \\
\hline Rectal cancer $=16$ & Transanal $=21$ & Rectum $=21$ & $4.6 \pm 1.7$ & $\begin{array}{l}\text { UTI=2 } \\
\text { Anastomotic leak=I } \\
\text { Impotence }=I\end{array}$ \\
\hline Rectal cancer $=7$ & Transanal=7 & Rectum $=7$ & $\begin{array}{l}\text { I.25 (mean) (range: } \\
0-2.5)\end{array}$ & Clavien-Dindo scale quantifying morbidities $\mathrm{I}-2=2$ \\
\hline Endometriosis $=63$ & & Left colon/sigmoid/ & Unk & Luminal bleed=5 (4.5\%) \\
\hline Diverticular $\mathrm{dz}=29$ & & rectum $=110$ & & Anastomotic leak $=I(0.91 \%)$ \\
\hline$C R C=15$ & & & & $\mathrm{UTI}=4(3.6 \%)$ \\
\hline Lipoma $=$ I & & & & High fever $=3(2.7 \%)$ \\
\hline $\begin{array}{l}\text { Ischemic stricture=I } \\
\text { Volvulus }=\mid\end{array}$ & & & & lleus $=I(0.91 \%)$ \\
\hline $\mathrm{CRC}=65$ & Transanal $=65$ & $\begin{array}{l}\text { Sigmoid }=27 \\
\text { Rectum }=38\end{array}$ & $2.9 \pm 1.5$ & $\begin{array}{l}\text { Intraperitoneal hemorrhage }=\mathrm{I}(\mathrm{I} .54 \%) \\
\text { Wound infection=I }(\mathrm{I} .54 \%) \\
\text { Anastomotic leak }=2(3.08 \%)\end{array}$ \\
\hline
\end{tabular}

(Continued) 
Table I (Continued)

\begin{tabular}{|c|c|c|c|c|c|c|}
\hline Study group & $\begin{array}{l}\text { Successful } \\
\text { NOSE/total } \\
\text { attempted }\end{array}$ & $\begin{array}{l}\text { Success } \\
\text { rate }(\%)\end{array}$ & $\operatorname{Sex}(M / F)$ & $\begin{array}{l}\text { Age (years) } \\
\text { Mean (range) }\end{array}$ & BMI mean (range) & Comorbidity \\
\hline
\end{tabular}

\begin{tabular}{|c|c|c|c|c|c|c|}
\hline $\begin{array}{l}\text { Akamatsu et al, }{ }^{44} \\
2009\end{array}$ & $16 / 16$ & 100 & Unk & Unk & Unk & Unk \\
\hline Cheung et al, ${ }^{45} 2009$ & $10 / 10$ & 100 & $4 / 6$ & $\begin{array}{l}66 \text { (median) (range: } \\
55-81 \text { ) }\end{array}$ & $\begin{array}{l}22 \text { (median) (range: } \\
19-27.5)\end{array}$ & Unk \\
\hline $\begin{array}{l}\text { Nishimura et al, }{ }^{46} \\
20 \mathrm{II}\end{array}$ & $17 / 18$ & 94.4 & $14 / 4$ & $\begin{array}{l}65.5 \text { (mean) (range: } \\
52-89 \text { ) }\end{array}$ & $\begin{array}{l}21.3 \text { (mean) (range: } \\
16.1-24.9)\end{array}$ & Unk \\
\hline Saad et $\mathrm{al}^{47} 2010$ & $8 / 8$ & 100 & $3 / 5$ & Unk & Unk & Unk \\
\hline $\begin{array}{l}\text { Wolthuis et al, } \\
201 \mathrm{I}\end{array}$ & $2|/ 2|$ & 100 & $2 / 19$ & $\begin{array}{l}\text { 4I (median) (range: } \\
34-66 \text { ) }\end{array}$ & $\begin{array}{l}23 \text { (median) (range: } \\
22-26)\end{array}$ & Unk \\
\hline Zorron et al, ${ }^{49} 2014$ & $7 / 9$ & 77.8 & $5 / 4$ & $\begin{array}{l}62.6 \text { (mean) (range: } \\
52-81 \text { ) }\end{array}$ & Unk & ASA $I / I I=9$ \\
\hline Huang et al, ${ }^{50} 2016$ & $32 / 32$ & 100 & $17 / 15$ & $68 \pm 13$ (range: 43-90) & $23.3 \pm 2.2$ (range: 18-27) & $\begin{array}{l}\text { ASA } I=4 \\
\text { ASA } \|=20 \\
\text { ASA } I \|=8\end{array}$ \\
\hline Leung et $a l^{51} 2013$ & $35 / 35$ & 100 & $13 / 22$ & $\begin{array}{l}62 \text { (median) (range: } \\
5 \mathrm{I}-86 \text { ) }\end{array}$ & Unk & Unk \\
\hline Kim et al, ${ }^{30} 2013$ & $57 / 58$ & 98.3 & $0 / 58$ & $62.8 \pm 9$ & $23.5 \pm 2.9$ & $\begin{array}{l}\text { ASA I=20 } \\
\text { ASA } I=32 \\
\text { ASA III =6 }\end{array}$ \\
\hline Denost et al, ${ }^{52} 2015$ & $122 / 122$ & 100 & $70 / 52$ & $\begin{array}{l}63 \text { (median) (range: } \\
20-90)\end{array}$ & 24.3 (median) (I7.3-33.6) & Unk \\
\hline Awad et al, ${ }^{35} 2014$ & $19 / 20$ & 95 & $0 / 20$ & $66.9 \pm 8.9$ & $25.1 \pm 6.65$ & $\begin{array}{l}\text { ASA } \|=4 \\
\text { ASA } \| I=I 5 \\
\text { ASA IV }=I\end{array}$ \\
\hline Park et $\mathrm{al}^{36} 20 \mathrm{II}$ & $32 / 34$ & 94.1 & $0 / 34$ & $61.0 \pm 11.2$ & $23.9 \pm 3.1$ & $\begin{array}{l}\text { ASA } I=12 \\
\text { ASA } \|=18 \\
\text { ASA } \| I=4\end{array}$ \\
\hline $\begin{array}{l}\text { Wolthius et al, }{ }^{16} \\
2011\end{array}$ & $2|/ 2|$ & 100 & Unk & $\begin{array}{l}35 \text { (median) (range: } \\
30-38 \text { ) }\end{array}$ & 23 (median) $(22-25)$ & $\begin{array}{l}\text { ASA } I=13 \\
\text { ASA } \|=8\end{array}$ \\
\hline
\end{tabular}




\begin{tabular}{|c|c|c|c|c|}
\hline $\begin{array}{l}\text { Indication/ } \\
\text { pathology }\end{array}$ & $\begin{array}{l}\text { Viscerotomy } \\
\text { site }\end{array}$ & Location & $\begin{array}{l}\text { Specimen size } \\
(\mathrm{cm})\end{array}$ & Complications \\
\hline Unk & $\begin{array}{l}\text { Transanal }=277 \\
\text { Transvaginal }=26\end{array}$ & Unk & Unk & $\begin{array}{l}\text { Transvaginal: none } \\
\text { Transanal: } \\
\text { Wound infection=2 }(0.7 \%) \\
\text { lleus=7 }(2.5 \%) \\
\text { UTI=6 }(2.2 \%) \\
\text { Bowel obstruction=I }(0.4 \%) \\
\text { Fecal incontinence=6 }(2.2 \%) \\
\text { Anastomotic leak=3 }(\mathrm{I} .1 \%)\end{array}$ \\
\hline $\begin{array}{l}\mathrm{CRC}=16 \\
\mathrm{TI} / \mathrm{T} 2\end{array}$ & Transanal $=16$ & $\begin{array}{l}\text { Sigmoid/ } \\
\text { rectosigmoid=16 }\end{array}$ & Unk & Wound infection=I (6.25\%) \\
\hline$C R C=10$ & Transanal $=10$ & $\begin{array}{l}\text { Rectosigmoid }=5 \\
\text { Sigmoid }=4 \\
\text { Descending } \\
\text { colon }=1\end{array}$ & Unk & None $(0 \%)$ \\
\hline$C R C=18$ & Transanal $=18$ & Sigmoid $=18$ & $\begin{array}{l}\text { I.84 (mean) (range: } \\
0-4.0)\end{array}$ & $\begin{array}{l}\text { Anastomotic leak }=I(5.56 \%) \\
\text { Wound infection }=I(5.56 \%) \\
\text { Enteritis=I }(5.56 \%)\end{array}$ \\
\hline Diverticulitis $=5$ & $C R C=3$ & Transanal $=8$ & $\begin{array}{l}\text { Left colon=8 } \\
\text { Length of specimen: } \\
\text { range } 16-34\end{array}$ & None $(0 \%)$ \\
\hline $\begin{array}{l}\text { Endometriosis }=13 \\
\text { Diverticulitis }=5 \\
C R C=3\end{array}$ & Transanal $=21$ & Sigmoid=2I & $\begin{array}{l}\text { Length of specimen: } \\
20 \text { (median) (range: } \\
\text { I3-25) }\end{array}$ & Anastomotic leak=I (4.8\%) \\
\hline$C R C=9$ & Transanal $=9$ & Rectum $=9$ & Unk & $\begin{array}{l}\text { Transitory feet neuralgia }=I \\
\text { Inadequate TME, tumor rupture }=I \\
\text { Anastomotic leak=I }\end{array}$ \\
\hline$C R C=32$ & Transanal $=32$ & $\begin{array}{l}\text { Sigmoid }=15 \\
\text { Rectosigmoid }=9 \\
\text { Upper rectum }=6 \\
\text { Mid rectum }=2\end{array}$ & $\begin{array}{l}3.3 \pm 1.8 \text { (range: } \\
\text { I.3-6.2) }\end{array}$ & $\begin{array}{l}\text { lleus=2 (6.24\%) } \\
\text { Wound infection=I (3.I2\%) }\end{array}$ \\
\hline$C R C=35$ & Transanal $=35$ & Left colon $=35$ & $\begin{array}{l}2 \text { (median) (range: } \\
2-4)\end{array}$ & None $(0 \%)$ \\
\hline$C R C=58$ & Transvaginal $=58$ & $\begin{array}{l}\text { Sigmoid }=21 \\
\text { Rectosigmoid }=8 \\
\text { Rectum }=29\end{array}$ & $3.4 \pm 1.8$ & $\begin{array}{l}\text { Bleeding }=I(I .7 \%) \\
\text { Intra-abdominal abscess=I }(I .7 \%)\end{array}$ \\
\hline$C R C=122$ & Transanal $=\mid 22$ & Low rectum $=122$ & $\begin{array}{l}3.9 \text { (median) (range: } \\
I-I 0)\end{array}$ & $\begin{array}{l}\text { Overall morbidity }=42(34 \%) \\
\text { Surgical morbidity (Clavien-Dindo scale quantifying } \\
\text { morbidities III })=18(15 \%) \\
\text { Mortality=I }(0.8 \%)\end{array}$ \\
\hline$C R C=20$ & Transvaginal $=20$ & Right colon $=20$ & $4.735 \pm 3.61$ & lleus $=2(10 \%)$ \\
\hline$C R C=34$ & Transvaginal $=34$ & $\begin{array}{l}\text { Cecum }=10 \\
\text { Ascending } \\
\text { colon }=16 \\
\text { Proximal } \\
\text { transverse colon=8 }\end{array}$ & $3.8 \pm 1.3$ & $\begin{array}{l}\text { Hemorrhage requiring transfusion=2 }(5.88 \%) \\
\text { lleus=I }(2.94 \%) \\
\text { Urinary retention=I }(2.94 \%)\end{array}$ \\
\hline $\begin{array}{l}\text { Bowel } \\
\text { endometriosis=21 }\end{array}$ & Transanal $=21$ & Sigmoid=2I & $\begin{array}{l}\text { Length of specimen: } \\
21 \text { (median) (range: } \\
\text { I7-24) }\end{array}$ & $\mathrm{UTI}=\mathrm{I}(4.76 \%)$ \\
\hline
\end{tabular}


Table I (Continued)

\begin{tabular}{lllllll}
\hline Study group & $\begin{array}{l}\text { Successful } \\
\text { NOSE/total } \\
\text { attempted }\end{array}$ & $\begin{array}{l}\text { Success } \\
\text { rate (\%) }\end{array}$ & Sex (M/F) & $\begin{array}{l}\text { Age (years) } \\
\text { Mean (range) }\end{array}$ & BMI mean (range) & Comorbidity \\
\hline Marks et al, ${ }^{18} 2017$ & $\begin{array}{l}193 / 193 \\
\text { (laparoscopic) }\end{array}$ & 100 & $135 / 58$ & 59 (mean) & 27 (mean) & ASA I=4 \\
& & & & ASA II=92 \\
ASA III=92 & ASA IV=5
\end{tabular}

Abbreviations: ASA, American Society of Anesthesiologists; BMI, body mass index; DVT, deep vein thrombosis; NOSE, natural orifice specimen extraction; prox., proximal; TME, total mesorectal excision; unk, unknown; UTI, urinary tract infection; CRC, colorectal cancer; FAP, familial adenomatous polyposis.

operation. Feasibility and complication rates for colorectal NOSE in patients with BMI $\geq 30 \mathrm{~kg} / \mathrm{m}^{2}$ require further study.

\section{Medical comorbidities}

NOSE in colorectal surgery has been successful in patients with ASA class III. Complication rates for this specific population are not reported. In a randomized clinical trial by Wolthuis et al, ${ }^{20}$ inflammatory response between conventional specimen extraction and NOSE was compared using postoperative C-reactive protein. C-reactive protein levels were found to be higher in the NOSE group, but ultimately, this was not associated with an increased length of hospital stay. The implications of this are unclear, but it could be suggested that patients with more comorbidities are less likely to tolerate a more robust inflammatory response. Conversely, use of pain scores in the same study was significantly lower in the NOSE group. In more frail patients with comorbidities, the advantage of decreased narcotic use is obvious.

Coagulopathy was set as the exclusion criterion in some NOSE colorectal studies. This should be considered as there is a reported rate of postoperative intraluminal hemorrhage of $4.5 \%{ }^{31}$ and intraperitoneal hemorrhage of $1.5 \%-3.7 \% .^{21,34}$ Transfusion was required in some of these patients, but all cases of postoperative bleeding resolved without another operation.

\section{Other potential patient factors}

History of prior operations and radiation exposure may influence the feasibility of any operation. While such history can make operations more challenging, there are no reported
NOSE failures that cite this as the reason for failure. In the context of rectal cancer treatment and taTME, neoadjuvant radiation is the standard of care. NOSE in this context has not been reported to be a significant issue. In our series of 373 patients with low rectal cancer treated with transanal abdominal transanal taTME, 100\% had successful NOSE via the anus when this approach was chosen.

\section{Specimen factors}

Review of the literature suggests that specimen factors such as size and shape are the most important factor in determining feasibility of successful NOSE in colorectal surgery. Preoperative assessment for this can be performed with computerized tomography scan or barium enema. The influential factors include length, location, and pathology. Table 1 lists the specimen-related factors with NOSE success rates for reviewed studies. Table 2 shows the specimen factors associated with failed NOSE in cases where the information was available.

\section{Size}

A majority of the literature regarding NOSE in colorectal surgery will describe specimen features by specimen length, width, and/or tumor size. Specimen traits that failed NOSE are often not discussed in detail and were only reported in one study. ${ }^{14}$ Success rates $>90 \%$ are seen in specimens with smaller diameter. Common exclusion criteria restrict NOSE to specimens of $<6.5 \mathrm{~cm}$ width. Karagul et $\mathrm{al}^{14}$ included patients with a wide range of specimen size (width $4.6 \pm 3.4$ $\mathrm{cm}$, length $25.2 \pm 22.6 \mathrm{~cm}$ ). The authors point out other aspects 


\begin{tabular}{|c|c|c|c|c|}
\hline $\begin{array}{l}\text { Indication/ } \\
\text { pathology }\end{array}$ & $\begin{array}{l}\text { Viscerotomy } \\
\text { site }\end{array}$ & Location & $\begin{array}{l}\text { Specimen size } \\
(\mathrm{cm})\end{array}$ & Complications \\
\hline$C R C=193$ & Transanal $=193$ & Low rectum $=193$ & Unk & $\begin{array}{l}\text { Anastomotic leak=4 }(\mathrm{I} .07 \%) \\
\text { Pelvic abscess=3 }(0.8 \%) \\
\text { Bleeding=2 }(0.54 \%) \\
\text { lleus=8 }(2.14 \%) \\
\text { Small bowel obstruction=3 }(0.8 \%) \\
\text { Acute kidney injury=I }(0.27 \%) \\
\text { Urinary sepsis=I }(0.27 \%) \\
\text { DVT/pulmonary embolism=3 }(0.8 \%) \\
\text { Arrhythmia }=2(0.54 \%) \\
\text { Wound infection=I }(0.27 \%) \\
\text { Ischemic bowel=2 }(0.54 \%) \\
\text { (open and laparoscopic pooled complications reported } \\
\text { only) }\end{array}$ \\
\hline
\end{tabular}

of the specimen which contribute to the feasibility of NOSE on a patient by patient basis: shape, location, and consistency. Reducing the bulk of specimens by transecting the mesentery has been described by Yagci et al. ${ }^{32}$ In this case report, a specimen with width $12 \mathrm{~cm}$ was removed via posterior colpotomy by partially dividing the mesentery. With this maneuver, the maximum width of the specimen was $9 \mathrm{~cm}$ compared to the initial width of $12 \mathrm{~cm}$. NOSE was successful in this patient. The tumor size for this right-sided colon adenocarcinoma was $5 \mathrm{~cm}$. This technique raises concerns about the long-term oncologic outcomes related to tumor implants. Laparoscopic bags and povidone-iodine have been used in attempts to minimize this risk. Long-term oncologic outcomes for mesentery transection are not available. It is unclear if this technique affects oncologic outcomes, but would be a safe option in the treatment of benign pathologies such as endometriosis, diverticulitis, and inflammatory bowel disease.

Length of the specimen also appears to be an important factor in NOSE feasibility. In Karagul et al's ${ }^{14}$ series, there was a statistically significant difference between specimen lengths in successful NOSE $(21.2 \pm 19.4 \mathrm{~cm})$ and failed NOSE $(36.5 \pm 27.6 \mathrm{~cm})$. Despite this, Palanivelu et $\mathrm{al}^{29}$ have demonstrated that total proctocolectomies via vaginal specimen extraction can be performed successfully. While specimen length contributes to NOSE feasibility, it must be considered in conjunction with specimen width, pathology, and location in the distal colorectum.

\section{Pathology}

In the context of colorectal malignancies, large tumors have been shown to contribute to NOSE failure. Benign colorectal pathologies associated with more inflammation, such as diverticulitis and inflammatory bowel disease, can also add to the bulk of specimens. This increased bulk, in turn, can theoretically increase the failure rate of NOSE, though this has not yet been demonstrated in the literature. NOSE has been demonstrated as feasible for diverticulitis and inflammatory bowel disease, though in each case, operations were performed on an elective basis and presumably had, at most, mild inflammation at the time of operation.

\section{Anatomic location}

Distal lesions are most amendable to successful NOSE. This is demonstrated by the high success rates of NOSE in taTME operations for rectal cancer. Karagul et al ${ }^{14}$ reported a $96.7 \%$ NOSE success rate for pathologies in the rectum and $54.5 \%$ for pathologies located in the colon. This is a $13.7-$ fold increase in the chance of NOSE failure with colonic resections as compared to rectal resections. Specimens of the rectum require a proctotomy as part of the distal margin transection that is already a required step in the operation. After the specimen is extracted, the proctotomy is then completely resected with another firing of a stapler in preparation for use of an end-to-end anastomosis (EEA) stapler, as demonstrated by Wolthuis et al. ${ }^{16}$ In our experience with low rectal cancers, the distal transection point of the specimen is at the dentate line and specimens were removed transanally in $100 \%$ of laparoscopic cases. A coloanal anastomosis using this already existing viscerotomy was created after specimen extraction.

As distance of the specimen from the anal verge increases, NOSE via the transanal route becomes more difficult. In right-sided colon pathology, many series have addressed this 


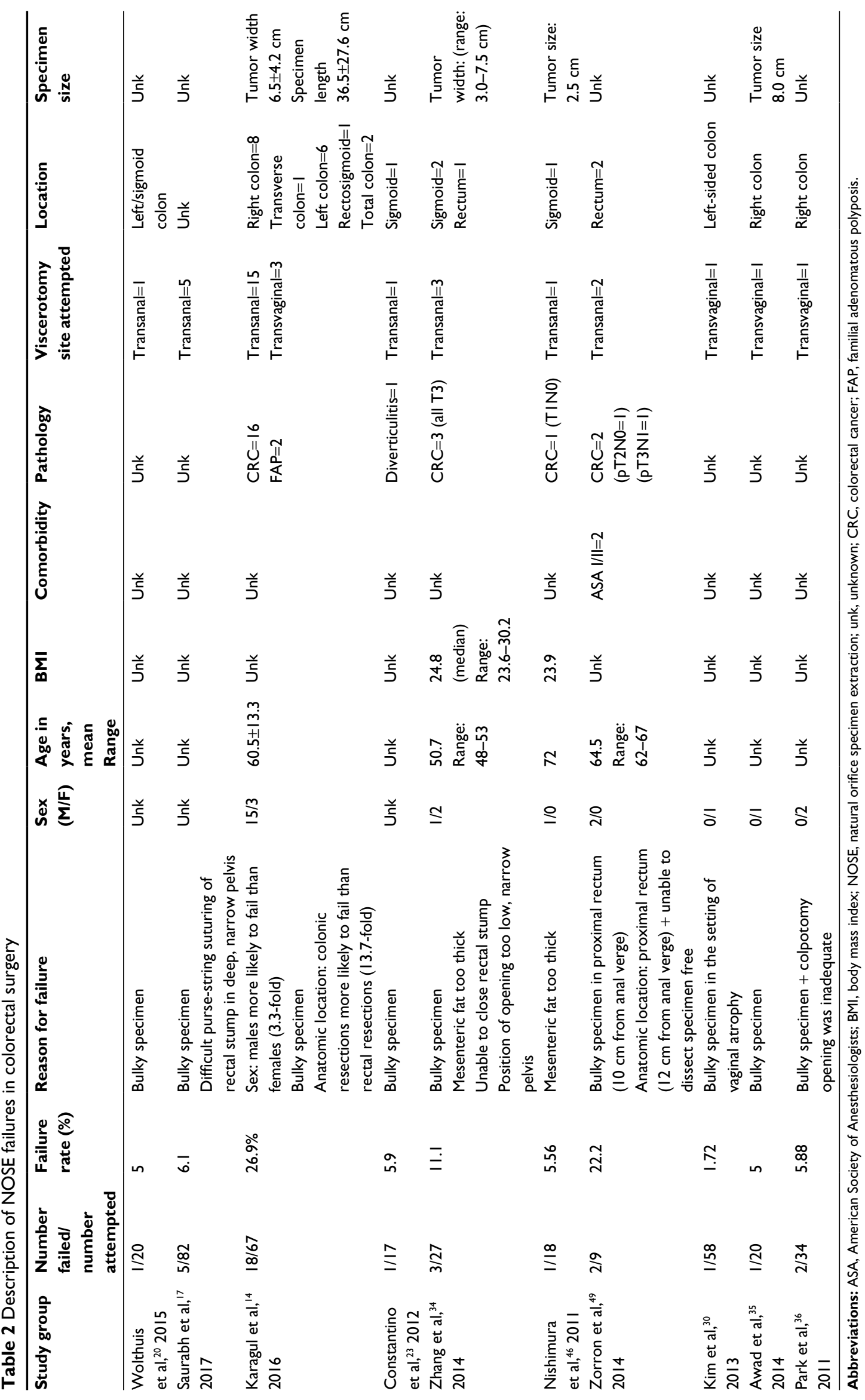


issue by removing the specimen transvaginally. ${ }^{11,35,36}$ This option is obviously available only to women, as discussed earlier.

\section{Discussion/future directions}

Beyond its established feasibility, short-term retrospective data and early randomized controlled trials do show advantages of NOSE compared to conventional specimen extraction in defined populations. While more randomized controlled trials are needed to compare the two techniques, potential benefits, including less postoperative analgesia, better cosmesis, quicker return of bowel function, and shorter hospital length of stay, can be significant. While this explains the motivation to utilize the NOSE technique, these favorable outcomes need to be considered in the context of their strictly selected patient populations.

Several patient and specimen factors are involved in determining the feasibility of NOSE for a given patient. It is not likely that any one of these factors would independently prevent NOSE unless the specific factor is an extreme deviation from the established patient population that is amendable to NOSE. Important patient factors are sex and BMI. Specimen factors are pathology, anatomic location, and size (width and length).

The role of NOSE in patients with BMI $>30$ requires more study. As incision-related complications are more common in obese patients, this population would stand to gain the most from avoiding a larger abdominal incision for specimen extraction. Feasibility of NOSE in this population is not well established and it has seldom been attempted. Higher BMI is associated with increased visceral fat, sometimes manifested as increased bulk of the mesentery. In the case of NOSE, a more bulky mesentery may prevent the removal of specimens by means of natural orifices altogether.

Another population that would benefit from avoidance of an abdominal incision for specimen extraction would be elderly patients and those with significant comorbidities. In general, as the burden of comorbidity increases, the more a patient would stand to gain by avoiding a larger abdominal incision. While reported postoperative morbidity in colorectal NOSE appears to be similar to that of conventional specimen removal, it is unclear if patients with less physiologic reserve would do as well. It is possible that the documented increased inflammatory response associated with NOSE would translate into inferior clinical outcomes. Future research should investigate the role of NOSE in these sicker patients, as a majority of the current literature involves patients with ASA classes I and II.
An attempt at NOSE does not prevent specimen removal via conventional means, thus, attempts at NOSE can be made with relatively low consequence. An algorithmic approach to attempting NOSE seems most reasonable. This is best demonstrated in the study design by Karagul et al. ${ }^{14}$ NOSE is first attempted by transanal means. If this fails and if the patient is a female, transvaginal specimen extraction is attempted, and in the experience of Karagul, it is often (80\%) successful. If this also fails, traditional specimen extraction can still be performed. As with any new surgical technique, if a surgeon attempts to add NOSE to their armamentarium, they should start with the easiest cases, selecting the most ideal patient. Surgeons performing NOSE should already be technically facile laparoscopically - in particular, intracorporeal anastomosis should already be a part of their skill set. As experience with NOSE increases for an individual surgeon, they can then select more difficult cases.

One of the greatest difficulties in reviewing the literature for NOSE in colorectal surgery is the wide heterogeneity in the operative technique ${ }^{10}$ between studies. Variances in technique include single-stapled versus double- or triple-stapled anastomosis and use of a specimen bag or wound protector for specimen removal. These variables can confound outcomes significantly. Introducing and implementing any new operative technique involve standardization, so that the skill can be taught and disseminated to achieve wider adoption. More recently, larger series including some randomized controlled trials have been performed in a consistent, clearly described, step-wise manner. As some of these studies have shown benefits in outcome, the operations as described in these studies would be the best framework for standardizing NOSE in colorectal surgery.

\section{Conclusion}

While the feasibility and benefits of NOSE have been demonstrated in the literature, patient selection plays a significant role in taking full advantage of this evolution in minimally invasive surgery. The benefits of NOSE need further study, particularly to see if the reported benefits can be generalized to larger populations. The ideal patient in whom NOSE would be feasible and beneficial is a non-obese (BMI <30) woman with pathology involving the distal colon or rectum where the specimen has a maximum width $<6.5 \mathrm{~cm}$. While each of these factors individually contributes to feasibility of NOSE, patient selection must continue to be on a caseby-case basis. Conversely, the patients who stand to benefit the most from avoidance of any abdominal wall extraction incision are morbidly obese and frail patients. While NOSE 
surgery offers an exciting option, careful study and adoption of this approach is mandated to ensure optimal patient benefit.

\section{Disclosure}

The authors report no conflicts of interest in this work.

\section{References}

1. Clinical Outcomes of Surgical Therapy Study Group, Nelson H, Sargent DJ, Wieand HS, et al. A comparison of laparoscopically assisted and open colectomy for colon cancer. N Engl J Med. 2004;350(20):2050-2059.

2. Colon Cancer Laparoscopic or Open Resection Study Group, Buunen M, Veldkamp R, Hop WC, et al. Survival after laparoscopic surgery versus open surgery for colon cancer: long-term outcome of a randomised clinical trial. Lancet Oncol. 2009;10(1):44-52.

3. Kennedy GD, Heise C, Rajamanickam V, Harms B, Foley EF. Laparoscopy decreases postoperative complication rates after abdominal colectomy: results from the national surgical quality improvement program. Ann Surg. 2009;249(4):596-601.

4. Hackert T, Uhl W, Buchler MW. Specimen retrieval in laparoscopic colon surgery. Dig Surg. 2002;19(6):502-506.

5. Kaminski JP, Pai A, Ailabouni L, et al. Role of epidural and patientcontrolled analgesia in site-specific laparoscopic colorectal surgery. JSLS. 2014;18(4):e2014.00207.

6. Ihedioha U, Mackay G, Leung E, Molloy RG, O’Dwyer PJ. Laparoscopic colorectal resection does not reduce incisional hernia rates when compared with open colorectal resection. Surg Endosc. 2008;22(3):689-692.

7. Winslow ER, Fleshman JW, Birnbaum EH, Brunt LM. Wound complications of laparoscopic vs open colectomy. Surg Endosc. 2002;16(10): 1420-1425.

8. Stewert EA, Liau AS, Friedman AJ. Operative laparoscopy followed by colpotomy for resecting a colonic leiomyosarcoma: a case report. $J$ Reprod Med. 1991;36(12):883-884.

9. Nezhat F. Laparoscopic segmental resection for infiltrating endometriosis of rectosigmoid colon: a preliminary report. Surg Laparosc Endosc Percutan Tech. 2001;11(1):67-68.

10. Wolthuis AM, de Buck van Overstraeten A, D'Hoore A. Laparoscopic natural orifice specimen extraction-colectomy: a systematic review. World J Gastroenterol. 2014;20(36):12981-12992.

11. Franklin ME Jr, Ramos R, Rosenthal D, Schuessler W. Laparoscopic colonic procedures. World J Surg. 1993;17(1):51-56.

12. Person B, Vivas DA, Wexner SD. Totally laparoscopic low anterior resection with transperineal handsewn colonic J-pouch anal anastomosis for low rectal cancer. Surg Endosc. 2006;20(4):700-702.

13. Eshuis EJ, Voermans RP, Stokkers PC, van Berge Henegouwen MI, Fockens P, Bemelman WA. Laparoscopic resection with transcolonic specimen extraction for ileocaecal Crohn's disease. Br J Surg. 2010;97(4):569-574.

14. Karagul S, Kayaalp C, Sumer F, et al. Success rate of natural orifice specimen extraction after laparoscopic colorectal resections. Tech Coloproctol. 2017;21(4):295-300.

15. Franklin ME Jr, Liang S, Russek K. Natural orifice specimen extraction in laparoscopic colorectal surgery: transanal and transvaginal approaches. Tech Coloproctol. 2013;17(Suppl 1):S63-S67.

16. Wolthuis AM, Meuleman C, Tomassetti C, et al. Laparoscopic sigmoid resection with transrectal specimen extraction: a novel technique for the treatment of bowel endometriosis. Human Reprod. 2011;26(6):1348-1355.

17. Saurabh B, Chang SC, Ke TW, et al. Natural orifice specimen extraction with single stapling colorectal anastomosis for laparoscopic anterior resection: feasibility, outcomes, and technical considerations. Dis Colon Rectum. 2017;60(1):43-50.

18. Marks JH, Myers EA, Zeger EL, Denittis AS, Gummadi M, Marks GJ. Long-term outcomes by a transanal approach to total mesorectal excision for rectal cancer. Surg Endosc. 2017;31(12):5248-5257.
19. Ma B, Huang XZ, Gao P, et al. Laparoscopic resection with natural orifice specimen extraction versus conventional laparoscopy for colorectal disease: a meta-analysis. Int J Colorectal Dis. 2015;30(11):1479-1488.

20. Wolthuis AM, Fieuws S, Van Den Bosch A, de Buck van Overstraeten A, D'Hoore A. Randomized clinical trial of laparoscopic colectomy with or without natural-orifice specimen extraction. Br J Surg. 2015;102(6):630-637.

21. Xingmao Z, Haitao Z, Jianwei L, Huirong H, Junjie H, Zhixiang Z. Totally laparoscopic resection with natural orifice specimen extraction (NOSE) has more advantages comparing with laparoscopic-assisted resection for selected patients with sigmoid colon or rectal cancer. Int J Colorectal Dis. 2014;29(9):1119-1124.

22. Wolthuis AM, Meuleman C, Tomassetti C, et al. How do patients score cosmesis after laparoscopic natural orifice specimen extraction colectomy? Colorectal Dis. 2015;17(6):536-541.

23. Costantino FA, Diana M, Wall J, Leroy J, Mutter D, Marescaux J. Prospective evaluation of peritoneal fluid contamination following transabdominal vs. transanal specimen extraction in laparoscopic left-sided colorectal resections. Surg Endosc. 2012;26(6):1495-1500.

24. Hisada M, Katsumata K, Ishizaki T, et al. Complete laparoscopic resection of the rectum using natural orifice specimen extraction. World $J$ Gastroenterol. 2014;20(44):16707-16713.

25. Kuhry E, Schwenk WF, Gaupset R, Romild U, Bonjer HJ. Cochrane Database Syst Rev. 2008;(2):CD003432.

26. Saida Y, Nagao J, Nakamura Y, et al. A comparison of abdominal cavity bacterial contamination of laparoscopy and laparotomy for colorectal cancers. Dig Surg. 2008;25(3):198-201.

27. Park JS, Choi GS, Kim HJ, Park SY, Jun SH. Natural orifice specimen extraction versus conventional laparoscopically assisted right hemicolectomy. Br J Surg. 2011;98(5):710-715.

28. Sehgal R, Cahill RA. Advanced laparoscopic surgery for colorectal disease: NOTES/NOSE or single port? Best Pract Res Clin Gastroenterol. 2014;28(1):81-96.

29. Palanivelu C, Rangarajan M, Jategaonkar PA, Anand NV. An innovative technique for colorectal specimen retrieval: a new era of "natural orifice specimen extraction" (N.O.S.E). Dis Colon Rectum. 2008;51(7):1120-1124.

30. Kim HJ, Choi GS, Park JS, Park SY, Ryuk JP, Yoon SH. Transvaginal specimen extraction versus conventional minilaparotomy after laparoscopic anterior resection for colorectal cancer: mid-term results of a case-matched study. Surg Endosc. 2014;28(8):2342-2348.

31. Wolthuis AM, de Buck van Overstraeten A, Fieuws S, Boon K, D'Hoore A. Standardized laparoscopic NOSE-colectomy is feasible with low morbidity. Surg Endosc. 2015;29(5):1167-1173.

32. Yagci MA, Kayaalp C, Novruzov NH. Intracorporeal mesenteric division of the colon can make the specimen more suitable for natural orifice specimen extraction. $J$ Laparoendosc Adv Surg Tech A. 2014;24(7):484-486.

33. Camhi SM, Bray GA, Bouchard C, et al. The relationship of waist circumference and BMI to visceral, subcutaneous, and total body fat: sex and race differences. Obesity (Silver Spring). 2011;19(2):402-408.

34. Zhang X, Zhou H, Hou H, Hu J, Wang H, Zhou Z. Totally laparoscopic resection with natural orifice specimen extraction for carcinoma of sigmoid colon and rectum: a feasible and innovative technique. J Clin Gastroenterol. 2014;48(7):e57-e61.

35. Awad ZT, Griffin R. Laparoscopic right hemicolectomy: a comparison of natural orifice versus transabdominal specimen extraction. Surg Endosc. 2014;28(10):2871-2876.

36. Park JS, Choi GS, Kim HJ, Park SY, Jun SH. Natural orifice specimen extraction versus conventional laparoscopically assisted right hemicolectomy. Br J Surg. 2011;98(5):710-715.

37. Wolthuis AM, De Buck Van Overstraeten A, D'Hoore A. Laparoscopic NOSE colectomy with a camera sleeve: a technique in evolution. Colorectal Dis. 2015;17(5):O123-O125.

38. Pai VD, Desouza A, De Menezes JL, Saklani AP. Laparoscopic intersphincteric resection and hand-sewn coloanal anastomosis: a natural orifice specimen extraction technique. J Laparoendosc Adv Surg Tech A. 2015;25(5):396-400. 
39. Nishimura A, Kawahara M, Honda K, et al. Totally laparoscopic anterior resection with transvaginal assistance and transvaginal specimen extraction: a technique for natural orifice surgery combined with reduced-port surgery. Surg Endosc. 2013;27(12):4734-4740.

40. Wang Q, Wang C, Sun DH, Kharbuja P, Cao XY. Laparoscopic total mesorectal excision with natural orifice specimen extraction. World J Gastroenterol. 2013;19(5):750-754.

41. Zhang XM, Wang Z, Hou HR, Zhou ZX. A new technique of totally laparoscopic resection with natural orifice specimen extraction (NOSE) for large rectal adenoma. Tech Coloproctol. 2015;19(6):355-360.

42. Han FH, Hua LX, Zhao Z, Wu JH, Zhan WH. Transanal natural orifice specimen extraction for laparoscopic anterior resection in rectal cancer. World J Gastroenterol. 2013;19(43):7751-7757.

43. Meillat H, de Chaisemartin C, Poizat F, et al. Combined NOTES total mesorectal excision and single-incision laparoscopy principles for conservative proctectomy: a single-centre study. Tech Coloproctol. 2017;21(1):43-51.

44. Akamatsu H, Omoro T, Oyama T, Masayuki T, Ueshima S, Masaaki N. Totally laparoscopic sigmoid colectomy: a simple and safe technique for intracorporeal anastomosis. Surg Endosc. 2009;23(11): 2605-2609.

45. Cheung H, Leung A, Chung CC, Ng CK, Li M. Endo-laparoscopic colectomy without mini-laparotomy for left-sided colonic tumors. World J Surg. 2009;33(6):1287-1291.
46. Nishimura A, Kawahara M, Suda K, Makino S, Kawachi Y, Nikkuni K. Totally laparoscopic sigmoid colectomy with transanal specimen extraction. Surg Endosc. 2011;25(10):3459-3463.

47. Saad S, Hosogi H. Natural orifice specimen extraction for avoiding laparotomy in laparoscopic left colon resections: a new approach using the McCartney tube and the tilt top anvil technique. J Laparoendosc Adv Surg Tech A. 2010;20(8):689-692.

48. Wolthuis AM, Pennickx F, D’Hoore A. Laparoscopic sigmoid resection with transrectal specimen extraction has a good short term outcome. Surg Endosc. 2011;25(6):2034-2038.

49. Zorron R, Phillips HN, Wynn G, Neto MP, Coelho D, Vassallo RC. "Downto-Up" transanal NOTES Total mesorectal excision for rectal cancer: preliminary series of 9 patients. J Minim Access Surg. 2014;10(3):144-150.

50. Huang CC, Chen YC, Huang CJ, Hsieh JS. Totally Laparoscopic colectomy with intracorporeal side-to-end colorectal anastomosis and transrectal specimen extraction for sigmoid and rectal cancers. Ann Surg Oncol. 2016;23(4):1164-1168.

51. Leung AL, Cheung HY, Fok BK, Chung CC, Li MK, Tang CN. Prospective randomized trial of hybrid NOTES colectomy versus conventional laparoscopic colectomy for left-sided colonic tumors. World J Surg. 2013;37(11):2678-2682.

52. Denost Q, Adam JP, Pontallier A, Celerier B, Laurent C, Rullier E. Laparoscopic total mesorectal excision with coloanal anastomosis for rectal cancer. Ann Surg. 2015;261(1):131-143.

\section{Clinical and Experimental Gastroenterology}

\section{Publish your work in this journal}

Clinical and Experimental Gastroenterology is an international, peerreviewed, open access, online journal publishing original research, reports, editorials, reviews and commentaries on all aspects of gastroenterology in the clinic and laboratory. This journal is included on PubMed. The manuscript management system is completely online

\section{Dovepress}

and includes a very quick and fair peer-review system, which is all easy to use. Visit http://www.dovepress.com/testimonials.php to read real quotes from published authors. 